\title{
Growth and descent of the testes in infants with hypogonadotropic hypogonadism receiving subcutaneous gonadotropin infusion
}

\author{
Anne-Sophie Lambert ${ }^{*}$ and Pierre Bougneres ${ }^{*}$
}

\begin{abstract}
Background: One third of infants with congenital hypogonadotropic hypogonadism $(\mathrm{CHH})$ are said to have micropenis and/or bilateral or unilateral cryptorchidism leading many of them to orchiopexy. Our previous study in two patients suggests that prolonged subcutaneous infusion of large doses of gonadotropins might normalize testicular function and growth.

Case presentation: To confirm the effects of early and prolonged subcutaneous infusion of large doses of gonadotropins on growth and descent of the testes. Eight boys with $\mathrm{CHH}$, aged $0.25-11$ months. Testes were non-palpable in 5 or in high scrotal position in 3. $\mathrm{CHH}$ was isolated in 5 infants and part of a syndrome of combined pituitary hormonal deficits in the 3 others. In response to gonadotropin infusion, mean levels of testicular hormones were normalized. Complete testis descent occurred in 6 patients. Partial descent occurred in 2. Testes re-ascended in 1 patient. Testes and penis gained normal dimensions in all cases.

Conclusion: Subcutaneous gonadotropin infusion seems able to induce testis descent in a large proportion of infants with $\mathrm{CHH}$. If confirmed, this may allow patients to avoid testes surgery but studies in larger series are needed to evaluate the benefits of this treatment versus traditional orchiopexy.
\end{abstract}

Keywords: Gonadotropin infusion, Testes descent, Congenital Hypogonadotropic Hypogonadism, Infancy

\section{Background}

Hypogonadotropic hypogonadism $(\mathrm{HH})$ is observed at birth in infants who have combined pituitary hormone deficits (CPHD) or isolated hypogonadotropic hypogonadism $(\mathrm{IHH})$, two separate entities that have separate and multiple genetic etiologies. Cryptorchid or maldescended testes and small testicular volume are clinical hallmarks of congenital hypogonadotropic hypogonadism $(\mathrm{CHH})$ [1]. We carried out a Pubmed search with the keywords "cryptorchidism", "cryptorchid testes", "testes descent", "CHH", "CPHD", "hypopituitarism", "Kallman", "isolated $\mathrm{HH}$ or idiopathic $\mathrm{HH}^{\mathrm{H}}$. Unexpectedly, this search retrieved only two studies allowing an

\footnotetext{
* Correspondence: ansolambert@gmail.com; pierre.bougneres@inserm.fr Department of Pediatric Endocrinology, Pôle I3E, Hôpital Bicêtre, Assistance Publique des Hôpitaux de Paris, Paris Sud University, Le Kremlin-Bicetre,
} France

estimation of the prevalence of cryptorchidism in patients half of them or unilateral in the other half $[2,3]$. Cryptorchidism, particularly if bilateral, is considered to have additional negative effects on the future fertility of patients I

A number of studies have examined the effect of man chorionic gonadotropin (hCG) or recombinan common cryptorchidism $[4,5]$. shese children, but rates generally do not exSurprisingly, a literature search found no comparable study in infants with $\mathrm{CHH}$, in whom hCG was largely 
used to test testosterone secretion [1], but not for therapeutic purposes. In the absence of a systematic study of hCG treatment upon testes descent in infants with either $\mathrm{IHH}$ or combined pituitary deficits, the data collected in common cryptorchidism are often used instead, but this extrapolation may not be justified. We know of only two studies, totaling 3 infants with $\mathrm{CHH}$, that have used gonadotropins in a therapeutic perspective. In the unique patient treated by Main et al., six months of twiceweekly subcutaneous injections of rhLH (20 IU) and rhFSH (21.3 IU) allowed a limited growth of the penis from 1.6 to $2.4 \mathrm{~cm}$ and a 1.7 -fold increase of testes volume [7]. In the two patients treated by Bougnères et al., subcutaneous infusion of rhLH and rhFSH at much higher daily doses of $50 \mathrm{IU}$ and $100 \mathrm{IU}$ were used to mimic mini-puberty in two infants with $\mathrm{CHH}$ [8]. This treatment induced a tripling of penile length and a 4fold increase in testes volume.

The other hormonal treatment that is classically used in infants with $\mathrm{CHH}$ is depot esters of testosterone [9]. Testosterone can be administered im, locally by a testosterone lotion or gel, transdermally by a testosterone patch or suppository. This treatment induces durable phallic growth but has no effect on testicular volume or descent. The lack of effect of testosterone alone upon testis descent contrasts with the classical hypothesis that the inguinoscrotal phase of testis descent, which takes place between the 25th and the 35th week of gestation but often occurs after birth in humans, is androgenmediated and is directly affected by the lack of testosterone production in fetuses with $\mathrm{CHH}[10]$.

The usual treatment of maldescended testes is surgical orchiopexy. For children with common, so-called "idiopathic" cryptorchidism, recommendations advocate orchiopexy at 6-12 months [11]. These recommandations contrasts with the report collected by Pitteloud et al. in patients with $\mathrm{IHH}$ [3]. This report indicates that surgical repair was performed in $86 \%$ of patients with cryptorchidism only between 4 and 35 years of age, at a mean age of $13 \pm 2$ years [3]. We have not been able to find a publication that has specifically examined or reviewed the indication, prevalence and long term results of orchiopexy in infants or children with $\mathrm{CHH}$ and cryptorchidism, whether they have IHH, including Kallman syndromes, or CPHD. This is even more surprising considering the fact that the surgical correction of cryptorchidism is advocated as a possible means for increasing the likelihood of future fertility $[12,13]$. Anecdotical reports of orchiopexy were found in a number of publications following a Pubmed search using keywords such as "orchiopexy", "CPHD", "hypopituitarism", "IHH", "Kallmann". See detailed comments and preferences in Additional file 1. These publications seems to indicate that orchiopexy is often used for the treatment of cryptorchidism in children with various genetic etiologies of $\mathrm{CHH}$, and that in most cases, orchiopexy is performed at age 4 years or later, confirming the observation of Pitteloud et al. [3]. The treatment of cryptorchidism thus remains a yet-to-be explored clinical field of research aiming at the preservation of fertility potential in patients affected with $\mathrm{CHH}$. The current study focuses on the effects of subcutaneous continuous recombinant $\mathrm{LH}$ and FSH infusion on the mal-descended testes in neonates with $\mathrm{CHH}$, with the idea of proposing this treatment as an alternative to orchiopexy.

\section{Case presentation}

Eight patients aged $6.03 \pm 3.75$ months $(0.25-11$ months) had $\mathrm{CHH}$ due to CPHD $(N=3)$ or IHH $(N=5)$. All infants had normal birth height and weight. All 8 patients had serum testosterone below $0.3 \mathrm{ng} / \mathrm{ml}$ (to convert into SI units, multiply by 3.47 , ie $1 \mathrm{nmol} / \mathrm{L}$ ) and $\mathrm{LH}<0.8 \mathrm{U} / \mathrm{l}$ during the time of physiological mini-puberty. The etiology of IHH was KAL1 mutations in two patients, KAL2 mutations in one patient, SOX2 mutation in one patient; one patient with IHH remained without molecular diagnosis. The 3 patients with CPHD had growth hormone, TSH, ACTH deficiencies and ectopic neuro-hypophysis. We have used the classification of cryptorchidism proposed by Scorer [14], where testis location is defined as normal, high scrotal, supra-scrotal, inguinal or non-palpable [15]. In our study, 5/8 patients had non-palpable testes and $3 / 8$ had palpable testes in a high non-scrotal position. Penile length was measured by the method of Schonfeld [16] the penis is stretched to resistance, and length is measured along the dorsal aspect from the pubis to the tip of the glans. Volume of the testes was carefully determined through palpation and direct measurement. Clinical characteristics of the patients are described in Table 1.

Following the favorable preliminary observations made in 2008 [8], we have since then routinely applied the subcutaneous infusion of rhLH and rhFSH to all infants with $\mathrm{CHH}$ referred in our department. The treatment started after explanations were given to the parents and consent was obtained. Ethical approval was obtained for the previous study from our local St Vincent Pediatric Ethical Committee (SVP-2007-04). rhLH (Luveris $75 \mathrm{IU}^{\circ}$ ) and rhFSH (Gonal-F $75 \mathrm{IU}^{\circ}$ ) were obtained from Serono (Geneva, Switzerland) and dissolved in solvent for infusion. A Paradigm insulin pump (Minimed, Northridge, CA) whose catheter was changed every $48-72 \mathrm{~h}$ was used for infusion. The biological stability of the infused rhLH and rhFSH within the pump system was ascertained by the stability of the plasma levels of $\mathrm{LH}$, 
Table 1 Characteristics of the 8 patients with $\mathrm{CHH}$ treated by rhLH and rh FSH infusion

\begin{tabular}{|c|c|c|c|c|c|c|c|c|c|}
\hline \multirow[t]{2}{*}{ Patients } & \multirow[t]{2}{*}{ Classification } & \multirow{2}{*}{$\begin{array}{l}\text { Age at onset } \\
\text { of treatment } \\
\text { (months) }\end{array}$} & \multicolumn{2}{|c|}{ Before treatment } & \multicolumn{5}{|l|}{ After treatment } \\
\hline & & & $\begin{array}{l}\text { Testes } \\
\text { position }\end{array}$ & $\begin{array}{l}\text { Penile length } \\
(\mathrm{mm})\end{array}$ & $\begin{array}{l}\text { Time to descent } \\
\text { (months) }\end{array}$ & $\begin{array}{l}\text { Testes volume } \\
\text { (ml) }\end{array}$ & Testes position & $\begin{array}{l}\text { Penile length } \\
(\mathrm{mm})\end{array}$ & $\begin{array}{l}\text { Duration of } \\
\text { treatment } \\
\text { (months) }\end{array}$ \\
\hline P1 & $\mathrm{CPHD}$ & 6 & $\begin{array}{l}\text { Non } \\
\text { palpable }\end{array}$ & 18 & 1 & 0.61 & High scrotal & 30 & 6 \\
\hline P2 & $\mathrm{CPHD}$ & 11 & $\begin{array}{l}\text { Non } \\
\text { palpable }\end{array}$ & 20 & 4 & 2 & Intra-scrotal & 33 & 6 \\
\hline P3 & $\mathrm{CPHD}$ & 10 & $\begin{array}{l}\text { High- } \\
\text { scrotal }\end{array}$ & 30 & 1 & 2,1 & Intra-scrotal & 70 & 6 \\
\hline P4 & $\mathrm{HH}$ & 4.5 & $\begin{array}{l}\text { Non } \\
\text { palpable }\end{array}$ & 21 & 4 & 0.76 & Intra-scrotal & 30 & 6.5 \\
\hline P5 & $\mathrm{HH}$ & 2.5 & $\begin{array}{l}\text { Non } \\
\text { palpable }\end{array}$ & 20 & 6 & 0.7 & $\begin{array}{l}\text { High-scrotal Intra- } \\
\text { scrotal }\end{array}$ & 35 & 6.5 \\
\hline P6 & $\mathrm{HH}$ & 9 & $\begin{array}{l}\text { Non } \\
\text { palpable }\end{array}$ & 19 & 4 & 1,16 & Intra-scrotal & 40 & 5 \\
\hline P7 & $\mathrm{HH}$ & 5 & $\begin{array}{l}\text { High- } \\
\text { scrotal }\end{array}$ & 28 & 4 & 0,89 & Intra-scrotal & 52 & 5 \\
\hline P8 & $\mathrm{HH}$ & 0.25 & $\begin{array}{l}\text { High- } \\
\text { scrotal }\end{array}$ & 13 & 5 & 1,95 & Intra-scrotal & 30 & 6 \\
\hline
\end{tabular}

$\mathrm{IHH}$ isolated hypogonadotropic hypogonadism, CPHD Combined Pituitary Hormonal Deficits (CPHD)

FSH, testosterone and inhibin B (INB) in the first two infants [8] when sampled at various times such as $12 \mathrm{~h}$ and $72 \mathrm{~h}$, the levels of these hormones were found to be steady. Continuous infusion of rhLH and rhFSH was administered at a daily rate of 50 and 75150 IU, respectively. These doses were used because we had previously observed that they allowed Leydig and Sertoli cell hormones to reach the normal range during minipuberty [17]. Indeed, daily infusion of 50 IU rhLH over 20 weeks induced LH levels of 4.8 $\pm 2.4 \mathrm{IU} / \mathrm{ml}$ and testosterone levels at $1.5 \pm 0.1 \mathrm{ng} / \mathrm{ml}$ in the two studied infants. For rhFSH infusion rates, we observed that high daily doses of 75-150 IU (resulting in FSH levels of $49 \pm 17 \mathrm{IU} / \mathrm{ml}$ ) were needed to obtain mean values of $\mathrm{AMH}$ and inhibin $\mathrm{B}$ (INB) levels of $563 \pm 204 \mathrm{pmol} / \mathrm{l}$ and $717 \pm 234 \mathrm{pg} / \mathrm{ml}$. In the current report, we have not tested graded infusions nor did we carry out a systematic dose-response study. Instead we started with daily doses of 50 IU rhLH and 75 IU of rhFSH, then used an approximate dose adjustment aiming at maintaining hormone levels within the normal range of mini-puberty [18, 19]. No adverse effects were observed at the cutaneous infusion site in any of the infants.

Classical replacement therapy with growth hormone, L-thyroxine, and hydrocortisone was administered to the patients with CPHD.

Serum FSH, LH, AMH, INB and testosterone concentrations were measured using RIA in the same laboratory as reported [20]. One-sided paired $t$ test was used to analyze the observed changes of penile length, testis volume and hormone levels.

Treatment duration was $6 \pm 0.58$ months. Follow-up after cessation of gonadotropin infusion was 35.5 months [13-54 months]. The continuous subcutaneous infusion of rhLH and rhFSH increased serum gonadotropins and testosterone, to values normally observed during minipuberty (Table 2). However, serum $\mathrm{AMH}$ and inhibin $\mathrm{B}$ both failed to reach the normal mini-puberty range in 1 / 8 patients.

Mean stretched penile length increased from $20.2 \mathrm{~mm}$ [13-28 $\mathrm{mm}]$ to $37.4 \mathrm{~mm}[30-52 \mathrm{~mm}](p<0.001)$ in infants with $\mathrm{IHH}$ and from $22.6 \mathrm{~mm}$ [18-30 mm] to $44.3 \mathrm{~mm}[30-70 \mathrm{~mm}](p<0.001)$ in infants with CPHD. Mean final testes volume was $1.27 \mathrm{ml}[0.61-$ $2.1 \mathrm{ml}$ ] Simultaneously, testicular volume increased from $0.43 \mathrm{ml}[0.1-0.68 \mathrm{ml}]$ to $1.64 \mathrm{ml}[0.33-2.1 \mathrm{ml}]$ $(p<0.001)$ in the 3 children who had testes palpable in high scrotal position. The details of testis descent are shown in Table 2. Among the 5 patients having their testes in abdominal position, bilateral descent to the bottom of the scrotum occurred in three (P2, P4 and P6) and bilateral incomplete descent in high scrotal position occurred in one (P1). One of the 5 patients with abdominal testes (P5) had a descent of his left testis to the bottom of the scrotum, while his right testis remained in high scrotal position. In total, among the 10 testes that were initially located in abdominal position, complete descent occurred in 7 , and incomplete descent in 3 . The three patients who 
Table 2 Serum concentrations of hormones before and during treatment

\begin{tabular}{|c|c|c|c|c|c|c|c|c|c|c|}
\hline & \multicolumn{5}{|c|}{ Before treatment } & \multicolumn{5}{|c|}{ During treatment } \\
\hline & $\overline{\mathrm{FSH}}(\mathrm{UI} / \mathrm{I})$ & $\mathrm{LH}(\mathrm{UI} / \mathrm{l})$ & $\mathrm{T}^{\mathrm{a}}(\mathrm{ng} / \mathrm{ml})$ & $\mathrm{AMH}(\mathrm{pmol} / \mathrm{l})$ & INB (pg/ml) & $\overline{\mathrm{FSH}}(\mathrm{UI} / \mathrm{I})$ & $\mathrm{LH}(\mathrm{UI} / \mathrm{l})$ & $\mathrm{T}(\mathrm{ng} / \mathrm{ml})$ & $\mathrm{AMH}(\mathrm{pmol} / \mathrm{l})$ & INB (pg/ml) \\
\hline \multicolumn{11}{|c|}{ Patients with CPHD } \\
\hline P1 & 0.4 & 0 & 0.06 & 103 & 5 & 18 & 1.2 & 1 & 264 & 55 \\
\hline P2 & 0.03 & $<0.1$ & 0.02 & 675 & 100 & 21 & 2.9 & 1.4 & 1644 & 505 \\
\hline P3 & 0.61 & 0.7 & 0.02 & 1984 & 155 & 18 & 2 & 2.8 & 1040 & 544 \\
\hline \multicolumn{11}{|c|}{ Patients with $\mathrm{IHH}$} \\
\hline P4 & 1 & 0.4 & 0.05 & 125 & 91 & 40 & 4.6 & 2.8 & 29 & 111 \\
\hline P5 & 0.8 & 0.1 & 0.04 & 595 & 73 & 24 & 4.7 & 3.3 & 565 & 401 \\
\hline P6 & 0.1 & $<0.1$ & 0.05 & 250 & 5 & 41 & 5.4 & 3.86 & 666 & 287 \\
\hline P7 & 0.3 & $<0.1$ & 0.02 & 665 & 64 & 32 & 4.6 & 3.9 & 668 & 514 \\
\hline P8 & 0.21 & $<0.1$ & 0.07 & 270 & 14 & 59 & 9.5 & 9.6 & 890 & 530 \\
\hline Mean value & 0.48 & 0.15 & 0.04 & 583 & 63.3 & $31^{b}$ & $4.4^{\mathrm{b}}$ & $3.6^{\mathrm{b}}$ & 721 & 368 \\
\hline Normal values ${ }^{c}$ & $0,2-4$ & $0,5-7,1$ & $0.52-4.8$ & $251-679$ & $254-513$ & $0,2-4$ & $0,5-7,1$ & $0.5-4.8$ & $251-679$ & $254-513$ \\
\hline
\end{tabular}

IHH isolated gonadotropin deficiency, CPHD Combined Pituitary Hormonal Deficits (CPHD), INB inhibin B

$T$ testosterone

${ }^{\text {a }}$ To convert T into SI unit (nmol/l), multiply by 3.47

${ }^{\mathrm{b}} p<0.005$ vs baseline values

${ }^{\mathrm{c}}$ Range of normal values taken from reference $[18,19]$

had testes initially palpable in high scrotal position showed complete scrotal descent during treatment. In one case (P4), however, both testes re-ascended 11 months after their descent, thus underwent orchiopexy. The cost of rhLH and rhFSH infusions per studied child over the 6 reported months averages 18,000 USD.

\section{Discussion}

A satisfactory sex life and fertility are the two main objectives of the treatment of $\mathrm{CHH}$. To allow for fertility, therapeutic regimens proposed in adulthood used the administration of hCG/HMG or hCG/rhFSH [21-25] or pulsatile GnRH with or without rhFSH in adolescents $[26,27]$. Cryptorchidism is estimated to affect approximately one third of patients with IHH $[2,3]$ and an important, but unknown proportion of infants with CPHD.

Patients affected with $\mathrm{CHH}$ who have cryptorchid testes have decreased hormonal response to gonadotropins at adolescence [26] or a less favourable fertility outcome [2] than those in whom spontaneous testis descent occurred at times of fetal or neonatal life. This may be due to intrinsic anomalies of the undescended testes, an acquired aggravation of testes abnormalities due to their prolonged intra-abdominal location [28], or could be secondary to lesions generated by surgical procedure needed to move an undescended testis into the scrotum, which carries a greater risk of damage to the testis when the testis is very small as in all infants with $\mathrm{CHH}$.

It is noteworthy in this respect that many of the studies reporting treatment outcomes in male patients with $\mathrm{CHH}$ were biased by the exclusion of patients with cryptorchidism [22, 24, 29-31]. The good therapeutic results that have been published regarding gonadotropin or $\mathrm{GnRH}$ treatment of $\mathrm{CHH}$ are thus likely to be less favorable if cryptorchid patients are included, as observed by Pitteloud et al. [2].

Boys with $\mathrm{CHH}$ lack all mini-pubertal hormonal events [32]. A potential contributor for azoospermia and infertility in adult men is the deficient proliferation of immature Sertoli cells in infancy due to FSH insufficiency. The artificial increase of Sertoli cell activity during early infancy might have beneficial effects on gonadal development, proliferation of immature Sertoli cells and spermatogonia that will help fertility in adult life, but this is entirely speculative. The current report on the effects of rhLH and rhFSH confirms our previous observation of correction of Sertoli and Leydig hormone pattern, and growth of phallus length and testes volume [8]. A new finding was the testicular descent observed in almost all treated patients. Despite the lack of an untreated group and the small number of studied infants, the current report suggests that early infusion of recombinant gonadotropins is able to trigger testes descent in children with $\mathrm{CHH}$, even when testes are initially in abdominal position. This effect was seen as late as the 17 months of life and therefore does not seem to be confined to the time of the physiological mini-puberty. The descent of testes occurred within a mean of four months following the onset of gonadotropins infusion, which may be beneficial since a recent study showed a negative relationship between the duration of a suprascrotal position and testicular growth [11]. In a few cases, the descent induced by gonadotropin infusion 
may be reversible, since testes re-ascended in one patient 11 months after their descent. Larger trials will be necessary to better define the window of efficacy of gonadotropin infusion for inducing testis descent.

Our choice of using large doses of rhFSH doses needs to be discussed. It was dictated by the previous observation in the first two reported infants [8], in whom we observed that daily dosages of $50 \mathrm{IU}$ rhFSH per day resulted in circulating levels of AMH and inhibin B well below the normal range. We then decided to increase the daily doses to 75-150 IU to force Sertoli cells to produce AMH and inhibin B at a more physiological level, as observed in the current report. We speculated that in patients born with both $\mathrm{HH}$ and cryptorchidism, there may be some resistance of Sertoli cells to FSH, possibly because of the prolonged lack of exposure to pituitary FSH during prenatal life.

Another aspect to be discussed in the current report is the deleterious effect that high circulating gonadotropin could have on germ cells in cryptorchid testes. Such deleterious effect have only been reported in boys with idiopathic cryptorchidism (with or without primary testicular insufficiency) treated with hCG, not in the $\mathrm{CHH}$ population, or in response to rhLH or rhFSH [33, 34].

\section{Conclusion}

The early continuous infusion of rhLH and rhFSH during the first months of life seems to allow the descent and growth of a large proportion of cryptorchid testes in infants with $\mathrm{CHH}$, as late as the 11th month of life. These preliminary observations raise several questions. Which of the two gonadotropins is responsible for the testis descent? Should this treatment replace the traditional orchiopexy in children with documented $\mathrm{CHH}$ ? Would repeated hCG injections allow comparable effects at a lower cost? hCG is recognized as of limited efficacy in infants with common cryptorchidism. It is thus possible, and even likely, that repeated hCG injections would prove of greater efficacy when cryptorchidism is related to gonadotrophin deficiency. Owing to its simplicity and low cost, this approach, which has not been studied previously in infants with $\mathrm{HH}$, will need a comparative evaluation in the future, both with orchiopexy and with the rhLH/rhFSH pump approach. Will the future fertility benefit from both the early descent of the testes and the stimulation of Sertoli cell function and/or proliferation induced by the rhLH and rhFSH infusion? Only prolonged follow-up of infants and large international trials will hopefully provide answers to the yetto-be solved problem of the early management of cryptorchidism in $\mathrm{CHH}$. In this regard, a possible merit of the current report is to bring the case of cryptorchidism associated with $\mathrm{CHH}$ in the frontline of future therapeutic approaches for preserving fertility potential in these patients.

\section{Additional file}

Additional file 1: Specific bibliography of orchiopexy in hypogonadotropic hypogonadism patients. (DOCX $147 \mathrm{~kb})$

\section{Abbreviations}

$\mathrm{CHH}$, Congenital Hypogonadotropic Hypogonadism; $\mathrm{HH}$, Hypogonadotropic Hypogonadism; CPHD, Combined Pituitary Hormonal Deficits; IHH, Isolated gonadotropin deficiency; rh, Recombinant; T, Testosterone; INB, Inhibin B

\section{Acknowledgements}

We thank Claire Bouvattier for her clinical care of the patients and for providing a careful critical survey of clinical data in patients' files. We acknowledge the help of Philippe Lucchini for setting and organizing the pump therapy.

\section{Authors' contribution}

ASL collected the data from patients' files for her MD thesis. PB set the protocol for gonadotropin infusion, made the initial observations about testicular descent and analyzed the literature. ASL and both contributed to write the manuscript. Both authors read and approved the final manuscript.

\section{Competing interests}

The authors declare that they have no competing interests.

\section{Consent for publication}

Written informed consent was obtained from the patient's legal guardian(s) for publication of this case report. A copy of the written consent is available for review by the Editor-in-Chief of this journal.

Received: 9 November 2015 Accepted: 26 May 2016

Published online: 04 July 2016

\section{References}

1. Grumbach MM. A window of opportunity: the diagnosis of gonadotropin deficiency in the male infant. J Clin Endocrinol Metab. 2005;90(5):3122-7.

2. Pitteloud N, Hayes FJ, Dwyer A, Boepple PA, Lee H, Crowley WF. Predictors of outcome of long-term GnRH therapy in men with idiopathic hypogonadotropic hypogonadism. J Clin Endocrinol Metab. 2002;87(9): 4128-36.

3. Pitteloud N, Hayes FJ, Boepple PA, DeCruz S, Seminara SB, MacLaughlin DT, et al. The role of prior pubertal development, biochemical markers of testicular maturation, and genetics in elucidating the phenotypic heterogeneity of idiopathic hypogonadotropic hypogonadism. J Clin Endocrinol Metab. 2002;87(1):152-60.

4. Henna MR, Del Nero RGM, Sampaio CZS, Atallah AN, Schettini ST, Castro AA, et al. Hormonal cryptorchidism therapy: systematic review with metanalysis of randomized clinical trials. Pediatr Surg Int. 2004;20(5):357-9.

5. Penson D, Krishnaswami S, Jules A, McPheeters ML. Effectiveness of hormonal and surgical therapies for cryptorchidism: a systematic review. Pediatrics. 2013;131(6):e1897-907.

6. Penson DF, Krishnaswami S, Jules A, Seroogy JC, McPheeters ML. Evaluation and Treatment of Cryptorchidism [Internet]. Rockville (MD): Agency for Healthcare Research and Quality (US); 2012

7. Main KM, Schmidt IM, Toppari J, Skakkebaek NE. Early postnatal treatment of hypogonadotropic hypogonadism with recombinant human FSH and LH. Eur J Endocrinol Eur Fed Endocr Soc. 2002;146(1):75-9.

8. Bougnères $P$, François $M$, Pantalone $L$, Rodrigue $D$, Bouvattier $C$, Demesteere E, et al. Effects of an early postnatal treatment of hypogonadotropic hypogonadism with a continuous subcutaneous infusion of recombinant follicle-stimulating hormone and luteinizing hormone. J Clin Endocrinol Metab. 2008;93(6):2202-5.

9. Bin-Abbas B, Conte FA, Grumbach MM, Kaplan SL. Congenital hypogonadotropic hypogonadism and micropenis: effect of testosterone treatment on adult penile size why sex reversal is not indicated. J Pediatr. 1999;134(5):579-83. 
10. Pierik FH, Deddens JA, Burdorf A, de Muinck K-SSMPF, de Jong FH, Weber RFA. The hypothalamus-pituitary-testis axis in boys during the first six months of life: a comparison of cryptorchidism and hypospadias cases with controls. Int J Androl. 2009;32(5):453-61.

11. Kollin C, Granholm T, Nordenskjöld A, Ritzén EM. Growth of Spontaneously Descended and Surgically Treated Testes During Early Childhood. Pediatrics. 2013;131(4):e1174-80.

12. King TFJ, Hayes FJ. Long-term outcome of idiopathic hypogonadotropic hypogonadism. Curr Opin Endocrinol Diabetes Obes. 2012;19(3):204-10.

13. Brito VN, Berger K, Mendonca BB. Male hypogonadism: childhood diagnosis and future therapies. Pediatr Health. 2010;4(5):539-55.

14. Scorer CG. THE DESCENT OF THE TESTIS. Arch Dis Child déc. 1964;39:605-9.

15. Bay K, Main KM, Toppari J, Skakkebæk NE. Testicular descent: INSL3, testosterone, genes and the intrauterine milieu. Nat Rev Urol. 2011;8(4):187-96.

16. Schonfeld WA, Beebe GW. Normal growth and variation in the male genitalia from birth to maturity. J Urol. 1942;48:759-77.

17. Lee MM, Misra M, Donahoe PK, MacLaughlin DT. MIS/AMH in the assessment of cryptorchidism and intersex conditions. Mol Cell Endocrinol. 2003;211(1-2):91-8.

18. Andersson AM, Toppari J, Haavisto AM, Petersen JH, Simell T, Simell O, et al. Longitudinal reproductive hormone profiles in infants: peak of inhibin B levels in infant boys exceeds levels in adult men. J Clin Endocrinol Metab. 1998;83(2):675-81.

19. Lahlou N, Fennoy I, Carel J-C, Roger M. Inhibin B and anti-Müllerian hormone, but not testosterone levels, are normal in infants with nonmosaic Klinefelter syndrome. J Clin Endocrinol Metab. 2004;89(4):1864-8.

20. Trabado S, Maione L, Bry-Gauillard H, Affres H, Salenave S, Sarfati J, et al. Insulin-like peptide 3 (INSL3) in men with congenital hypogonadotropic hypogonadism/Kallmann syndrome and effects of different modalities of hormonal treatment: a single-center study of 281 patients. J Clin Endocrinol Metab. 2014;99(2):E268-75.

21. Liu L, Banks SM, Barnes KM, Sherins RJ. Two-year comparison of testicular responses to pulsatile gonadotropin-releasing hormone and exogenous gonadotropins from the inception of therapy in men with isolated hypogonadotropic hypogonadism. J Clin Endocrinol Metab. 1988;67(6):1140-5.

22. Bouloux P, Warne DW, Loumaye E, FSH Study Group in Men's Infertility. Efficacy and safety of recombinant human follicle-stimulating hormone in men with isolated hypogonadotropic hypogonadism. Fertil Steril. 2002;77(2):270-3.

23. Young J, Chanson P, Salenave S, Noël M, Brailly S, O'Flaherty M, et al. Testicular anti-mullerian hormone secretion is stimulated by recombinant human FSH in patients with congenital hypogonadotropic hypogonadism. J Clin Endocrinol Metab. 2005;90(2):724-8.

24. Warne DW, Decosterd G, Okada H, Yano Y, Koide N, Howles CM. A combined analysis of data to identify predictive factors for spermatogenesis in men with hypogonadotropic hypogonadism treated with recombinant human follicle-stimulating hormone and human chorionic gonadotropin. Fertil Steril. 2009;92(2):594-604.

25. Matsumoto AM, Snyder PJ, Bhasin S, Martin K, Weber T, Winters S, et al. Stimulation of spermatogenesis with recombinant human follicle-stimulating hormone (follitropin alfa; GONAL-f): long-term treatment in azoospermic men with hypogonadotropic hypogonadism. Fertil Steril. 2009;92(3):979-90.

26. Bouvattier C, Tauber M, Jouret B, Chaussain JL, Rochiccioli P. Gonadotropin treatment of hypogonadotropic hypogonadal adolescents. J Pediatr Endocrinol Metab JPEM. 1999;12 Suppl 1:339-44.

27. Raivio T, Wikström AM, Dunkel L. Treatment of gonadotropin-deficient boys with recombinant human FSH: long-term observation and outcome. Eur J Endocrinol Eur Fed Endocr Soc. 2007;156(1):105-11.

28. Sykiotis GP, Hoang X-H, Avbelj M, Hayes FJ, Thambundit A, Dwyer A, et al. Congenital idiopathic hypogonadotropic hypogonadism: evidence of defects in the hypothalamus, pituitary, and testes. J Clin Endocrinol Metab. 2010;95(6):3019-27.

29. Burgués S, Calderón MD. Subcutaneous self-administration of highly purified follicle stimulating hormone and human chorionic gonadotrophin for the treatment of male hypogonadotrophic hypogonadism. Spanish Collaborative Group on Male Hypogonadotropic Hypogonadism. Hum Reprod. 1997:12(5):980-6.

30. Liu PY, Turner L, Rushford D, McDonald J, Baker HW, Conway AJ, et al. Efficacy and safety of recombinant human follicle stimulating hormone (Gonal-F) with urinary human chorionic gonadotrophin for induction of spermatogenesis and fertility in gonadotrophin-deficient men. Hum Reprod Oxf Engl. 1999;14(6):1540-5.
31. Okuyama A, Nakamura M, Namiki M, Aono T, Matsumoto K, Utsunomiya M, et al. Testicular responsiveness to long-term administration of hCG and hMG in patients with hypogonadotrophic hypogonadism. Horm Res. 1986;23(1):21-30.

32. Kumar PA, Pitteloud N, Andrews PAM, Dwyer A, Hayes F, Crowley WF, et al. Testis morphology in patients with idiopathic hypogonadotropic hypogonadism. Hum Reprod Oxf Engl. 2006;21(4):1033-40.

33. Christiansen P, Müller J, Buhl S, Hansen OR, Hobolth N, Jacobsen BB, et al. Treatment of cryptorchidism with human chorionic gonadotropin or gonadotropin releasing hormone. A double-blind controlled study of 243 boys. Horm Res. 1988;30(4-5):187-92.

34. Dunkel L, Taskinen S, Hovatta O, Tilly JL, Wikström S. Germ cell apoptosis after treatment of cryptorchidism with human chorionic gonadotropin is associated with impaired reproductive function in the adult. J Clin Invest. 1997;100(9):2341-6.

\section{Submit your next manuscript to BioMed Central and we will help you at every step:}

- We accept pre-submission inquiries

- Our selector tool helps you to find the most relevant journal

- We provide round the clock customer support

- Convenient online submission

- Thorough peer review

- Inclusion in PubMed and all major indexing services

- Maximum visibility for your research

Submit your manuscript at www.biomedcentral.com/submit

) Biomed Central 